\title{
THE EXPORT MEAT INDUSTRY
}

\author{
Bruce Curtis \\ University of Canterbury
}

Recent work on industrial change has emphasized shifts from mass production to flexible production. These are organisational transformationsand may be seen as responses to the decline of mass markets and the need for niche marketing.

The market-oriented approach has gained considerable popularity in framing an account of reorganisation in the meat industry. While it is convenient to portray crisis and change in the industry in terms of the mass production flexible production dualism (Perry, 1992). This abstraction is not necessarily correct.

This paper argues that the changes in the export meat industry do not equate with those encapsulated as the shift from mass production to flexible production. Farmers played a pivotal role in the traditional organisation of the industry. They are likely to retain considerable independence in the future. The influence of farmers across the export meat industry is decisive in the disparity between idealised models of industrial change and its actuality in the export meat industry.

The export meat industry in New Zealand actually became organised as a very peculiar variant of mass production. The ensuing construction of markets in the high volume export of frozen meats most aided independent farming. This variant of mass production is called the Producers' System.

The Producers' System represented relationships between farmers, processors and markets which were dominated by farmers and secured through the state. Its formal elements are the Meat Producers' Board and the producers' co-operative meat companies (Hussey, 1992).

The future of the meat industry does not correspond with flexible production. It is more likely to appear as an admixture of mass production and flexible production. This industrial combination is called 'networked production' (Salais and Storper, 1992).

\section{Four 'worlds' of production}

Salais and Storper attempt to move beyond the mass production - flexible production dualism. They do so by identifying four distinct production logics or 'worlds' of production. These are ideal types created by a complex interplay of product and markets as suggested in Figure 1.
The nature of the market influences the capacity for firms to calculate risk and fluctuations in demand. Where such calculations are possible, markets are certain or predictable. Where they are not possible markets are uncertain.

Market certainty is also closely linked to the product. Predictable product-markets are typically anonymous. There is no direct contact between sellers and buyers. Price is the main determinant of demand. Traded products are generic. On the other hand, uncertain markets require closer relationships between sellers and buyers. Exact quality is the main determinant of demand and traded products are typically dedicated to buyer specification.

The nature of the production process is also important . The techniques and methods of production may exist as a set of readily available, standardised, processes. On the other hand, production processes may require expert, specialised, knowledge.

Production may be organised to accrue benefits of high volume through-put (economies of scale) or benefits of variety (economies of scope). When bounded in these terms industry coalesces around four worlds of production which we label here as named mass production, network production, flexible production, and futuristic production.

Each world of production is centred on a distinct logic of operation which can be regarded as underpining the organisational response to environment and change. Salais and Storper identify contesting sub-components of profitmaximization underlying each world of production (Salais and Storper, 1992:172).

These four contesting elements of profit-maximisation in Figure 1 provide a framework for the analysis of labour markets and product markets. Although the notions associated with futuristic production will not be used.

\section{Mass production.}

Mass production normally requires a hierarchical construction of the market. That is, firms are driven to secure supply, processing and distributional capacities through strategies of vertical integration (Chandler, 1978). This organisational response to mass markets produces oligopolies.

Nevertheless, competition between firms remains based in price competition. Mass producers act as cost minimisers. 
FIGURE 1. FOUR 'WORLDS' OF PRODUCTION.

\section{SPECIALISED PROCESS STANDARDISED PROCESS}

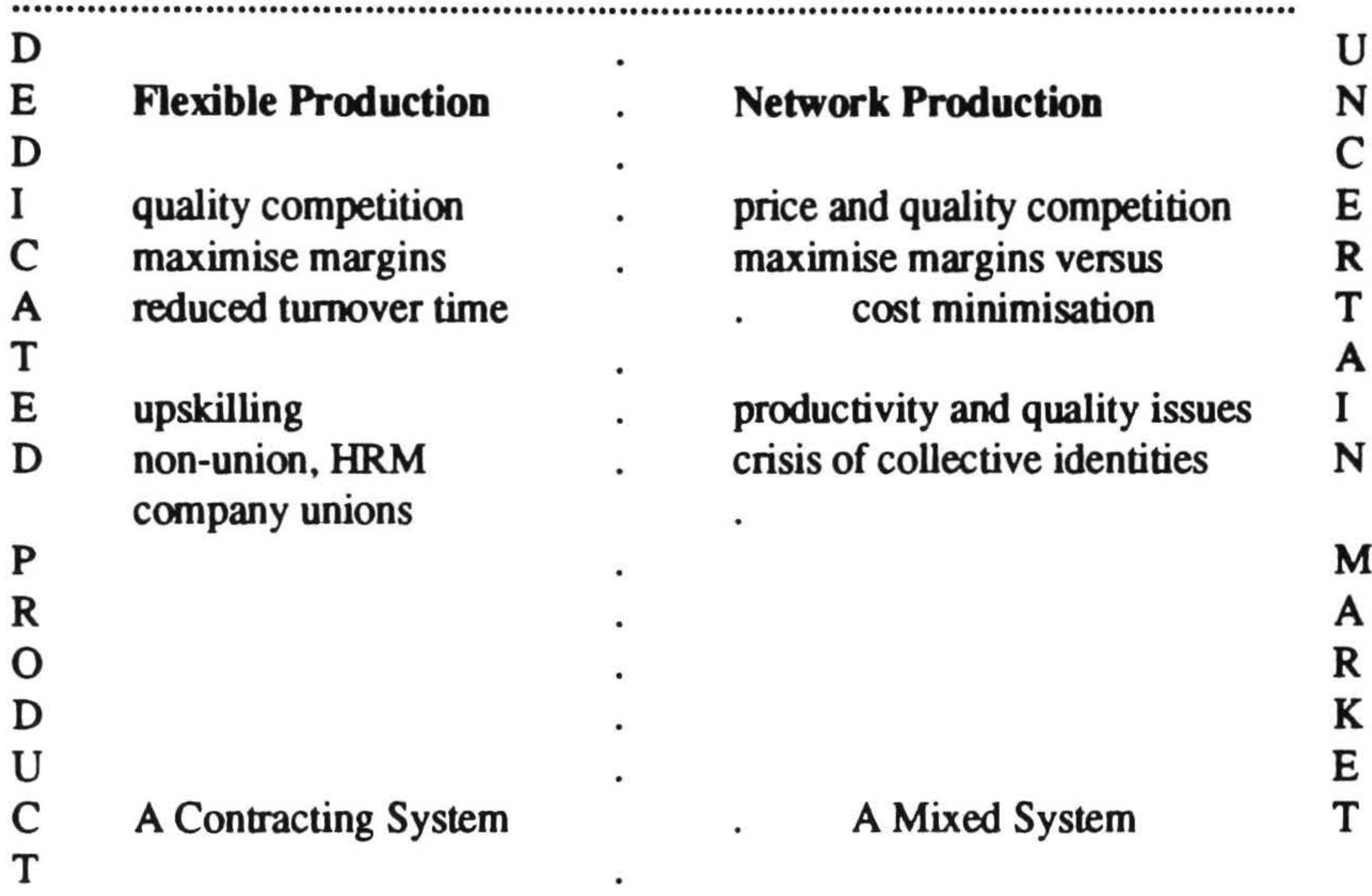

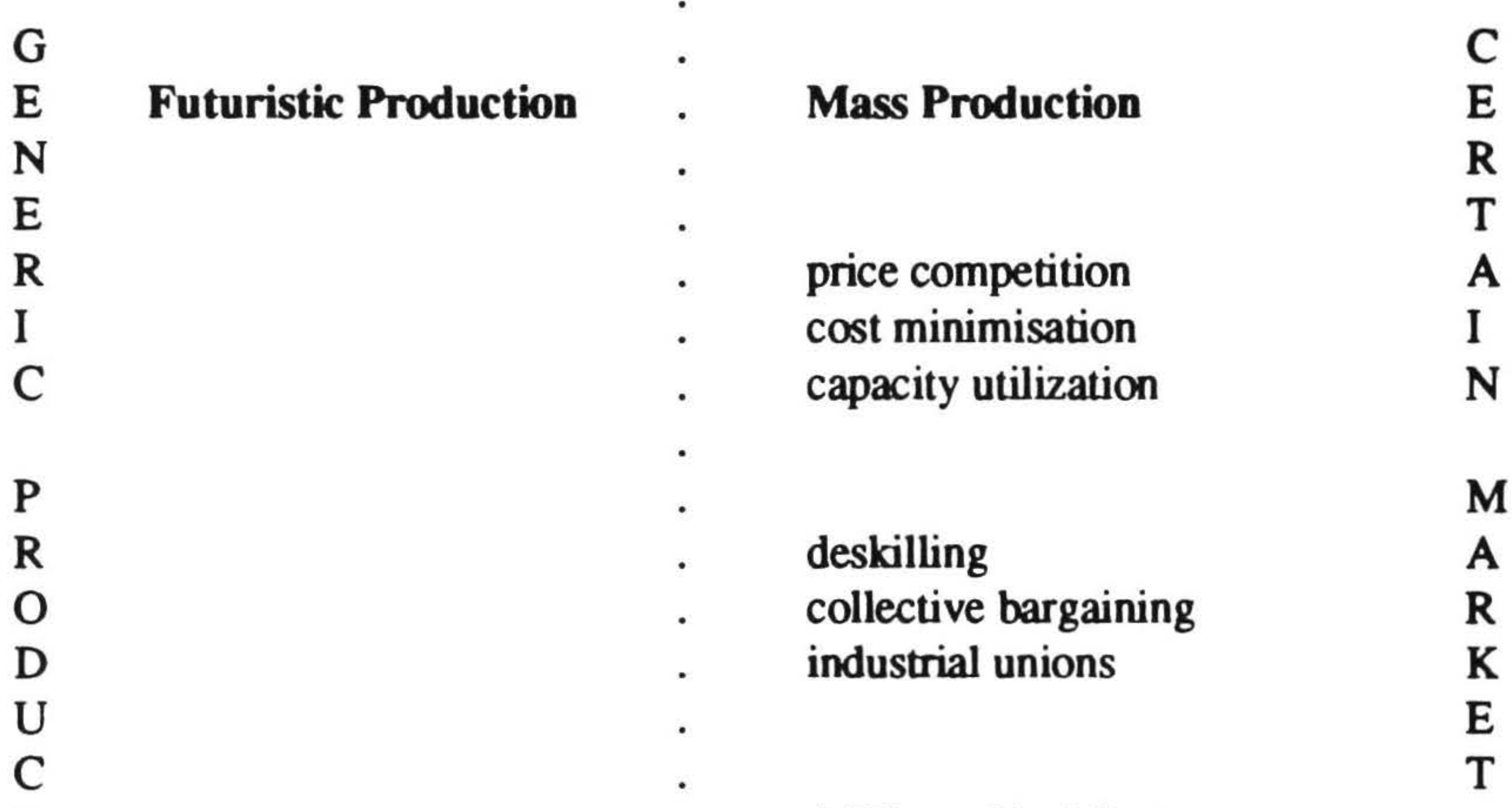

Two key profit-maximising techniques are pursued. Both impact on the labour process and on industrial relations. They are related to the efficient use of capital and labour.

Mass producing firms seek maximum capacity utilization and constant improvements in labour productivity. Both strategies reflect the drive to minimise unit costs (price competition).

\section{Flexible production.}

Flexible production is the mirror-image of mass production. Flexible production normally requires a contracted construction of the market, that is, markets are established through inter-firm agreements and not intra-firm strategies. The organisational response to niche-markets entails a strong disincentive to secure supply, processing, or distributional capacity that may not be used.

The characteristics of dedicated products are not easily encompassed into price-cost calculations. Competition is based on quality rather than prices. Flexible producing firms seek to maximise profit margins. To do so they attempt to minimise turn-over times and set-up times. 
Network production exists as an contradictory amalgam of elements of mass production and flexible production. The main tension results from incentives to combine dedicated production with economies of scale. This is the organisational response to niche markets where benefits of high volume through-put still accrue. Price and quality competition co-exist.

Networked markets are also mixed. Inter-firm and intra-firm arrangements co-exist. The idealised 'mass producer' and the 'flexible producer' each bring advantages and disadvantages into the market. Strategies of cost minimisation collide with those maximising margins.

\section{The organisation of work}

Sorge and Streeck (1988) focus is on industrial relations in the context of industrial change and their 'extended perspective' provides a coherent framework to situate product markets and labour markets. These are mediated at the organisational level by profit-maximising firms.

Sorge and Streeck privilege organisational choice and, in particular, product strategies. Their typology locating product strategies is related to the four words of production. Product strategy and work organisation "are related to crucial organisational environments - the former to the product and the latter to the labour market." (Sorge and Streeck, 1988: 39). They likewise move beyond the rise of 'flexible specialisation' which they identify as too closely associated with small, independent craft firms (Sorge and Streeck, 1988: 31).

Within the world of mass production the organisation of work is primarily shaped by the cost minimising dynamic. The resulting labour processes and forms of industrial relations are influenced by (i) Taylorism and deskilling of the labour process (Braverman, 1974), (ii) the collective bargaining over wages and conditions, and (iii) the emergence of industrial unionism.

The organisation of work within the world of flexible production is shaped by the drive for 'bespoke manufacture'. Labour processes and 'industrial relations' are influenced by (i) upskilling of the labour process, (ii) non-union systems of labour management, including Human Resource Management, HRM, or (iii) the tendency for company unionism.

The organisation of work within the world of network production is pulled in different directions. This results in (i) sharp struggles over productivity and quality in the labour process and (ii) an endemic crisis of collective identities (Pizzorno, 1978).
Both of the aforementioned models of organisational choice and industrial change need modification before they can be effectively applied to the export meat industry. These models, like the cruder ones, draw upon a manufacturing metanarrative.

The manufacturing metanarrative reflects a longstanding prejudice in social theory against agriculture and the social relations of agricultural production. As a result, these models will not adequately account for choice or change in a production system based on farming.

These agro-commodity systems (Friedland, 1984; Le Heron, 1988) represent special cases within worlds of production. Two particular relaxations in modelling are required. The first relates to the presence of nature in production (Mann and Dickinson, 1978; Goodman, Sorj and Wilkinson, 1987). The second relates to the dominance of household producers in farming rather than profitmaximising firms (Friedmann, 1978; Reinhardt and Barlett, 1989).

The key to understanding agro-commodity systems is to focus on struggles between the dominant forms of industry (agribusiness) and the dominant form of farming (household production). This struggle inevitably results in the subordination of one form of production to the other.

In Argentina independent farming became subordinated to agribusiness (to distributional and processing activities). This subordination was so complete and lasting that there the export meat industry was equivalent to mass production.

In New Zealand independent farming defeated agribusiness (Font, 1990). The logic of operation in processing and to a lesser extent in distribution was subordinated to the demands of household farming. A comparison between Argentina and New Zealand is therefore instructive in highlighting the differences between the Producers' System and mass production.

\section{Argentina vs New Zealand}

The export meat industries in Argentina and New Zealand represented only part of an international trade in meat. As such the industries shared a number of organisational dynamics (Critchell and Raymond, 1912).

Both export meat industries emerged in the 1880 s when advances in refrigeration technology allowed the transportation of frozen meat. The dominant market in both case was the United Kingdom.

Farming in both countries enjoyed a rapid growth in livestock numbers. These animals were processed onshore and exported by refrigerated ships as frozen carcases. The frozen carcases were distributed in the United Kingdom 
by an oligopoly of meat companies. The UK distributional system was based in wholesaling (Harrison, 1963).

The technologies of processing were developed in the US during the 1870s. The production technologies associated with bulk refrigeration and conveyor disassembly were fully disseminated by the turn of the century.

The largest meat companies were UK and US owned. Their operations were global. As Chandler notes these meat companies were among the first to pursue strategies of vertical integration. They operated as food manufacturers (Burns, 1983). Where possible they implemented strategies to minimise unit costs.

\section{Argentina and mass production.}

The export meat industry in Argentina was formed mainly by backward integration of US meatpacking companies. Swifts, Armour and others constructed large processing plants and these plant directly adopted the technologies of US meatpacking. This technological edge was probably decisive in displacing the British companies which had arrived a decade earlier than the Americans. By world war one (WW1) all UK meat companies with the exception of Vesteys (Knightley, 1980) had been forced from Argentina.

Meat processing in Argentina resembled its more famous counterpart in Chicago. The slaughter and dressing of livestock was centralised and undertaken in multi-storied buildings, there conveyor dis-assembly and gravity allowed an organisation of work which captured true economies of scale and of scope-integration (sequential economies of of scale). 'Everything but the moo' was converted into meat and by-products.

Braverman notes that this organisation of work was a precursor to Taylorism and to deskilling (Braverman, 1974: 81). In North America it became the foundation of industrial unionism (Novek, 1989). Process and distribution (shipping and the UK wholesale depot system) was tightly controlled by the large US/UK meat companies. A monopsony relationship in the purchase of livestock (few buyers and many sellers) was created and this encouraged the subordination of farming.

Many small farmers were impoverished and some corporate farming was undertaken. More importantly, the subordination of farming forced the transformation of farming practices to better suit the demands of processing for continuous and predictable through-put. The extension of this logic of operation (mass production) now entails the use of growth hormones and the feedlotting of animals (Sanderson, 1986). These developments transformed agriculture into an industrial pattem of production.

\section{New Zealand and the Producers' System.}

The Producers' System in New Zealand was constituted by the formation of the Meat Producers' Board (1922) and licensing of the industry (1934). Both of these statutory interventions reflect the ability of independent farming to effectively defend its interests.

The Meat Board and industry licensing were responses to the strategies of vertical integration pursued by UK/US meat companies after WW1. These posed an undeniable threat to independent farming in New Zealand. Foreign meat companies attempted to use a collapse in agricultural prices (1921) and the long depression to expand their influence in New Zealand and these developments had the potential to reorganise the relationship between farming and processing along Argentine lines.

Unlike Argentina, processing capacity had been constructed in New Zealand by farmers and farming interests. The largest local meat companies even established toe-holds in the United Kingdom. But without ready access toUK distribution a number of small local companies went broke in the decade after WW1 (Hereford, 1932). Several meat plants were closed-down or fell into foreign ownership. This was despite the best efforts of other local companies to support them.

Mainly because of farmers extensive off-farm investments, processing in New Zealand has from the outset been characterised by over-capacity and low rates of utilization. The spread of processing capacity has been beneficial to farmers. It has ensured a geographic overlap in the catchment areas of meat companies and forced competition for livestock. As a result, farmers have enjoyed above 'normal' prices for their output.

The formal constitution of the Producers' System secured an historical relationship between farming and processing that farmers were no longer able to defend through off-farm investment. The struggles between farmers and food manufactures along the agro-commodity system were fixed in the interests of household producers.

\section{The organisation of work in the meat industry.}

Processing is the key labour market in the export meat agro-commodity system. This arena is also structured by the victory of independent farming over food manufacture and the organisation of work is clearly influenced by the dynamics of the Producers' System.

The early meat plants in New Zealand were very different to those in the Argentine/US. The original processing sites were constructed as simple 'killing shed'. These operated for the slaughter and dressing of livestock from the catchment area. Disruptions in the availability of livestock made their operation discontinuous on a daily and seasonal basis.

As livestock numbers increased through-put increased and daily discontinuities were smoothed-out. In Argentina the logic of mass production, based on high volumes and the subordination of farming, resulted in the smoothing- 
out of annual capacity usage. Economies of scale and of scope-integration accrued in processing. While the export meat industry in New Zealand was likewise based on high volumes the Producers' System prevented comparable patterns of processing. Hence, the local labour process is characterised by the belated introduction of economies of scale and of scope-integration.

Processing in New Zealand however remained labour intensive. The key workforce were solo-butchers who undertook the entire process of slaughtering and dressing sheep. This work was organised around craft skills and not the Taylorised dis-assembly line of US meatpacking. Even when conveyor dis-assembly (the chain) was introduced in 1932, almost sixty years after its appearance in the Americas, it failed to produce a significant improvement of capacity utilisation. Deskilling, machine-pacing, and improved workflows are all manifestations of mass production. The local (New Zealand) literature is preoccupied with the first two elements without recognising the collision between the logics of food manufacture and of independent farming. The labour process in the industry is understood with little regard for the extraordinary influence of the Producers' System. It is explored in terms of manufacture and with analogies to a literature based on the US auto industry (Geare, 1972; Howells and Alexander, 1968; Inkson, 1977; Inkson and Simpson, 1975).

Conveyor dis-assembly was first installed by a British meat company in an effort to subvert the efforts of the Meat Producers' Board. The Board was then restricting foreign expansion by refusing to certify extra solo-butchers in Borthwicks plants (Harrison, 1963). Transforming the labour process was primarily designed to evade this regulation. It failed insofar as the response to the chain system was the statutory licensing of the industry.

The chain was configured in local processing as a series of parallel lines. These parallel lines represented a fundamentally different approach to the unilinear configuration of US meatpacking. By the 1940 s processing plants typically involved the operation of 2 or 3 'chains'. Only one chain would commence operation at the start of the killing season. All chains would operate at the peak of the season. As the numbers of livestock available for slaughter petered-off processing capacity was reduced in discrete steps through the closure of chains.

This arrangement cannot be understood in terms of cost minimisation. The configuration of parallel lines represents the subordination of the motives of mass production to those of independent farming. In short, the subordination of a continuous production process to a discontinuous production process.

The main discontinuity in pastoral farming is expressed as seasonality. The configuration of parallel lines in processing represents both a flexible response to seasonal livestock production and an admission of defeat on the part of agribusiness. Food manufacture was unable to enforce the transformation of farming practices in New Zealand. Instead processing attempted to best match the seasonal fluctuations in farm production.

\section{Industrial relations in the meat industry.}

The confrontation between farming and food manufacture gave organised labour considerable room for manoeuvre. For example, while the chain system deskilled work it failed to increase labour productivity. In fact, the implementation of the chain system resulted in what has been called 'the greatest go-slow in industrial history'. Meatworkers (as opposed to solo-butchers) regained considerable job control after the appearance of the chain system (Cammock and Inkson, 1988).

Despite their militancy and economic centrality, organised labour did not evolve along the lines of industrial unionism. The meatworkers unions have never operated as a national body and the worksite has remained central to bargaining pay and conditions. The exclusionary practices associated with seniority have formed a central tenet of worksite organisation.

In many regards organised labour is the mirror-image of the processing capitals it confronts. Both are decentralised and disaggregated. Both owe as much to the demands of independent farming as of food manufacture.

\section{A new world of production}

A new world of production is emerging. This is likely to be a form of network production as this is characterised in Figure 1. Its major features are the uneasy combination of mass production and flexible production. The motor of change is the disintegration of the mass market.

Boosted foreign production, the new hegemony of retail distribution and protectionism have all destabilised product-markets. Yet the dynamic from economies of scale remains only it is recast by the demands of product dedication. Quality and the exact timing of delivery are of increasing importance along the agro-commodity system.

Just-in-time and total quality management strategies now appear as standard production processes. The labour process is increasingly subject to surveillance linked to total quality management (TQM). Struggles centred on the labour process increasing blur issues of productivity and quality. Organised labour is faced by new management strategies and the likelihood of company unions.

Likewise farmers are increasingly subject to the techniques of TQM and the discipline of highly specific contracts. This raises the spectre of a new subordination. But, the continued influence of farmers allows them considerably greater room for manoeuvre than the small suppliers described in the flexible production literature. Independent farmers are no longer directly threatened by the backwards integration of old-style meat companies. 
And it seems unlikely that they will be easily subordinated by the new-entrant niche-marketers.

The formal role of the state as the protector of independent farming will continue to decline. At the same time, the independence of household farming is likely to be secured by a variety of niche-markets, and by a combination of spot, contracted and hierarchical arrangements. The organisational form that will gain ascendency in this new environment is the joint venture. It combines inter-firm with intra-firm arrangements. Joint ventures can be forms of organisation that operate over both the short-term or the long-term.

A number of joint ventures are already apparent along the agro-commodity system. Many link producers' cooperatives with retailing companies (PPCS and Bernard Mathews; AFFCo and Itoh Ham).The ability of farmers to respond to a changing environment highlights the common misconception regarding 'deregulation'. Despite a decade of deregulation (Cloke, 1989; Perry 1992) independent farming remains viable. Farmers are emerging not as the victims of change but as the agents of change.

\section{Summary and Conclusion}

The utility of the 'manufacturing metanarrative' in explaining the complex reality of industrial change in an industry bounded by farming has been challenged in this paper. Extrapolations of the mass production-flexible production dualism are unable to account for historical and contemporary organisations of the industry. A pervasive bias against the social relations of farming must be overcome before any genuine understanding of organisational strategies, the labour process and industrial relations can be achieved.

\section{Future Research}

This paper has sketched some key research questions, in the form of the initial findings from a broad research project. These are located in the fields of theory and method. On the one hand, there is a tendency for one-sided theorizing to dominate. One the other hand, research must be guided by more than a familiarity with 'the literature'. The specificity of an industry which bridges farming and manufacture remains largely unaccounted for.

\section{References}

Braverman, H. 1974 Labour and Monopoly Capital. Monthly Review Press, New York.

Burns, J. 1983 A synoptic view of the food industry The Food Industry: Economics and Politics Burns, J., J. McInerney, and A. Swinbank, London, Heinemann.

Cammock, P and Inkson, K. 1988 The meat freezing industry in New Zealand Technology and the Labour
Process Willis, E., Allen and Unwin, Sydney: 68 $-80$.

Chandler, A.D. 1978 The Visible Hand: The Managerial Revolution in American Business, Belknap, Harvard.

Cloke, P. 1989 State deregulation and New Zealand's agricultural sector Sociologia Ruralis 29, 1: 34 48.

Critchell, J. T. and Raymond, J. 1912 A History of the Frozen Meat Trade Constable and Co., London.

Font, M. A. 1990 Export agriculture and development path: Independent farming in comparative perspective Journal of Historical Sociology 3, 4: $329-361$.

Friedland, W.H. 1984 Commodity systems analysis: an approach to the sociology of agriculture Research in Sociology and Development 1: 221 - 235.

Friedmann, H. 1978 Simple commodity production and wage labour in the American plains The Journal of Peasant Studies 6, 1:71 - 99.

Geare, A.J. 1972 The problem of industrial unrest: theories into the causes of local strikes in a New Zealand meat freezing works Journal of Industrial Relations 14: 13-22

Goodman, D., B. Sorj, and J. Wilkinson, 1987 From Farming to Biotechnology: A Theory of AgroIndustrial Development Basil Blackwell, Oxford.

Harrison, G. 1963 Borthwicks: A Century in the Meat Trade, 1863 - 1963 Borthwicks, London.

Hereford, P.S.E. 1932 The New Zealand Frozen Meat Trade NZ Publishing Co. Wellington.

Howells, J.M. and R.P.A. Alexander 19_ The KerrSeigel hypothesis and the meat freezing industry in New Zealand New Zealand Economic Papers 2: $35-47$

Hussey, D. 1992 Agricultural Marketing Regulation: Realityversus Doctrine, NZ Business Roundtable, Wellington.

Inkson, J.H.K. 1977 The man on the dis-assembly line: New Zealand freezing workers. Australian and New Zealand Journal of Sociology 13:2-11

Inkson, J.H.K. and D. Simpson 1975 The assembly-line and alienation: a participant-observer study in the meat industry New Zealand Psychologist 4: 44-55 
Knightley, P. 1980 Various articles: 5 October - 2 November The Sunday Times London: various pages.

Le Heron, R. 1988 Reorganisation of the New Zealand Export Meat FreezingIndustry: Political Dilemmas and Spatial Impacts, Massey University, Palmerston North.

Mann, S. A., and J.M. Dickinson 1978 Obstacles to the development of a capitalist agriculture The Journal of Peasant Studies 5, 4: 466 - 481.

Novek, J. 1989 Peripheralising core labour markets?: The cases of the Canadian meat packing industry Work, Employment and Society 3, 2:157 - 178.

Perry, N. 1992 Upside down or downside up? Sectoral interests, structural change and public policy Controlling Interests J. Deeks and Perry, N., Auckland University Press, Auckland: 36 - 58.

Pizzorno, A. 1978 Political exchange and collective identity in industrial change The Resurgence of Class Conflict in Western Europe since $1968 \mathrm{C}$. Crouch and Pizzorno, A., MacMillan, London: 277 - 298.

Reinhardt, N., and Barlett, P. 1989 The persistence of family farms in United States agriculture Sociologia Ruralis 29, 3: 203 - 225.

Salais, R., and Storper, M. 1992 The four 'worlds' of contemporary industry Cambridge Journal of Economics, 16: 169 - 193.

Sanderson, S.E. 1986 The emergence of the 'world steer': Internationalisation and foreign domination in Latin American cattle production Food, the State and International Political Economy F.L. Twillis and Hollist, W.L, University of Nebrasksa Press, London: 123 - 148.

Sorge, A., and Streeck, W. 1988 Industrial relations and technical change: The case for an extended perspective New Technology and Industrial Relations R. Hyman and Streeck, W, Basil Blackwell, Oxford: 19 - 47. 